УДК 347.73:336.22

Селезень Павло Олександрович

кандидат юридичних наук, старший науковий співробітник, провідний науковий співробітник НДІ фіскальної політики,

Університет ДФС України, Ірпінь, Україна, pselezen@i.ua

\title{
СУТНІСТЬ, ЕВОЛЮЦІЯ ТА РОЛЬ ВЗАЄМОУЗГОДЖУВАЛЬНОЇ ПРОЦЕДУРИ ЯК МЕХАНІЗМУ ВИРІШЕННЯ ПОДАТКОВИХ СПОРІВ
}

У сучасному світі питання механізмів вирішення спорів у сфері оподаткування $\epsilon$ актуальним з огляду на процеси поглиблення глобалізації та кризовий стан глобальної фінансової системи. Відсутність ефективних механізмів вирішення спорів, пов'язаних із тлумаченням і застосуванням норм договорів про уникнення подвійного оподаткування, зумовлює перегляд уже існуючих інструментів та віднайдення нових. Ціль статті полягає у характеристиці сутності, еволюції та ролі взаємоузгоджувальної процедури як механізму вирішення спорів, що виникають на основі тлумачення та застосування договорів про уникнення подвійного оподаткування. Методологічну основу дослідження складають діалектичний, порівняльноправовий та системний методи. Взаємоузгоджувальна процедура визнається унікальним договірним механізмом вирішення спорів щодо тлумачення та застосування норм договорів про уникнення подвійного оподаткування. Історія його розвитку започатковується у міжвоєнний період шляхом включення відповідних положень у модельні акти Ліги Націй у сфері оподаткування. Тривала практика використання такого механізму підтверджує виправданість його існування у сучасному світі з точки зору наявних переваг не лише для компетентних органів, але і для платників податків. Разом 3 тим, обмежена практика його використання у поєднанні 3 наявністю проблемних аспектів у контексті забезпечення балансу публічного та приватного інтересу у сфері оподаткування переконує у тому, що потенціал взаємоузгоджувальної процедури використовується ще далеко не в повній мірі. В умовах високого рівня недовіри до дій судової та виконавчої гілок в Україні та необхідності забезпечення інвестиційної привабливості взаємоузгоджувальна процедура $\epsilon$ потенційно перспективним інструментом 3 точки зору забезпечення балансу приватного та публічного інтересу.

Ключові слова: взаємоузгоджувальна процедура, ОЕСР, міжнародні податкові договори, адміністративне співробітництво, оподаткування. 
Selezen Pavlo, Candidate of Juridical Sciences, senior researcher, Research Institute of Fiscal Policy leading resercher, University of State Fiscal Service of Ukraine, Irpin, Ukraine

\section{Meaning, evolution and role of mutual agreement procedure as a tax dispute resolution mechanism}

The relevance of the study is determined by the fact that the issue of a tax dispute resolution is actual in the context of the globalization processes and global financial crisis state. The lack of effective mechanisms for resolving disputes related to the interpretation and application of the double taxation treaties rules leads to the revision of existing instruments and the detection of new ones. Main objective of the study is to characterize a meaning, stages of evolution and role of mutual agreement procedure as a dispute resolution mechanism in the area of interpretation and application of double taxation treaties provisions. The methodology of research includes dialectical and comparative, and system analysis method. Mutual agreement procedure is defined as a unique treaty dispute resolution mechanism for interpretation and application of double taxation treaties provisions. Its history is traced back to the interwar period (1918-1939) by including of the respective provisions in the League of Nations model norms within taxation sphere. Long practice of mutual agreement procedure application determines its relevance in modern world and demonstrates its attractiveness for competent authorities and taxpayers. At the same time, the limited practice of its usage in combination with the presence of problematic aspects in the context of providing a balance between public and private interest in the field of taxation convinces that the potential of the interconnection procedure still to be far from being fully used. In conditions of a high level of distrust to the judicial and executive branches in Ukraine and the need to ensure investment attractiveness, the interharmonization procedure becomes a potentially promising tool in terms of a balance of private and public interest ensuring.

Key words: mutual agreement procedure, OECD, international tax treaties, administrative cooperation, taxation.

Селезень Павел Александрович, кандидат юридических наук, стариий научный сотрудник, ведущий научный сотрудник НИИ фискальной политики Университета ГФС Украины, г. Ирпень, Украина

Сущность, эволюция и роль взаимосогласительной процедуры как механизма разрешения налоговых споров

В современном мире вопросы механизмов разрешения споров в сфере налогообложения являются актуальными, принимая во внимание процессы углубления глобализации и кризисное состояние глобальной финансовой системы. Отсутствие эффективных механизмов разрешения споров, связанных с толкованием и применением норм договоров об избежании двойного 


\section{СУТНІСТЬ, ЕВОЛЮЦІЯ ТА РОЛЬ ВЗАЕМОУЗГОДЖУВАЛЬНОЇ ПРОЦЕДУРИ ЯК МЕХАНІЗМУ ВИРІШЕННЯ ПОДАТКОВИХ СПОРІВ}

налогообложения, обуславливает пересмотр уже существующих инструментов и разработку новых. Цель статьи состоит в характеристике сущности, эволюции и роли взаимосогласительной процедуры как механизма разрешения споров, возникающих в связи с толкованием и применением договоров об избежании двойного налогообложения. Методологическую основу исследования образуют диалектический, сравнительно-правовой и системный методы. Взаимосогласительная процедура признается уникальным договорным инструментом разрешения споров относительно толкования и применения норм договоров об избежании двойного налогообложения. История его развития начинается в межвоенный период путем включения соответствующих положений в модельные нормы Лиги Наций в сфере налогообложения. Продолжительная практика использования такого механизма подтверждает оправданность его существования в современном мире с точки зрения существующих преимуществ не только для компетентных органов, но и для налогоплательщиков. Вместе с тем, ограниченная практика его использования в сочетании с существованием проблемных аспектов в контексте обеспечения баланса публичного и частного интереса в сфере налогообложения убеждает в том, что потенциал взаимосогласительной процедуры использован далеко не в полной мере. В условиях высокого уровня недоверия к действиям судебной и исполнительной веток власти в Украине и необходимости обеспечения инвестиционной привлекательности взаимосогласительная процедура является потенциально перспективным инструментом с точки зрения обеспечения баланса частного и публичного интереса.

Ключевые слова: взаимосогласительная процедура, ОЭСР, международные налоговые договора, административное сотрудничество, налогообложение

Вступ. Статистика держав-членів ОЕСР щодо вирішення податкових спорів 3 використанням потенціалу взаємоузгоджувальної процедури переконливо свідчить не лише про позитивну динаміку, але і про розширення географії застосування відповідного інструменту. Так, якщо у 2005 р. в Бельгії було розпочато взаємоузгоджувальну процедуру лише у 31-му випадку, в Канаді - в 76-ти, в Німеччині - у 212-ти, то у 2015 р. відповідно у 428-и, 130-ти та 363-х випадках. Такі ж юрисдикції як Словаччина, Словенія, Туреччина за той же період часу отримали перший досвід використання взаємоузгоджувальної процедури як інструменту вирішення спорів щодо тлумачення та застосування норм договорів про уникнення подвійного оподаткування [11]. У поєднанні 3 включенням обов'язку щодо вдосконалення механізмів вирішення податкових спорів 3 використанням взаємоузгоджувальної процедури в мінімальний пакет заходів кампанії щодо протидії розмиванню бази оподаткування та переміщення 
прибутків в низько податкові юрисдикції (далі - БЕПС) подібні тенденції вказують на необхідність забезпечення належного розуміння сутності відповідних механізмів та їх особливостей з урахуванням світового досвіду.

Аналіз останніх досліджень і публікацій вказує на те, що хоча дослідники $з$ далекого зарубіжжя, зокрема, 3. Альтман, Р. Ісмер, М. Ломбардо, М. Ніттел, приділяли увагу різним аспектам взаємоузгоджувальної процедури починаючи від історичних аспектів ії виникнення і закінчуючи особливостями закріплення в модельних актах ОЕСР - у вітчизняній науці відповідна тема належним чином не висвітлена. Саме тому є потреба в узагальнені підходів до визначення сутності та ролі відповідного механізму вирішення податкових спорів.

Ціль статті полягає у характеристиці сутності, еволюції та ролі взаємоузгоджувальної процедури як механізму вирішення спорів, що виникають на основі тлумачення та застосування договорів про уникнення подвійного оподаткування.

Основний матеріал дослідження. Експерти ОЕСР зазначають, що процедура взаємного узгодження на основі договорів про уникнення подвійного оподаткування «дозволяє уповноваженим сторонам (компетентним органам) від урядів договірних держав взаємодіяти 3 наміром вирішення міжнародного податкового спору. Такі спори включають як подвійне оподаткування (юридичне i економічне), так і неузгодження в тлумаченні та застосуванні податкового договору» $[9$, с. 8]. Сутність взаємоузгоджувальної процедури М. Ломбардо визначає так: «Взаємоузгоджувальна процедура $є$ спеціальним механізмом за рамками внутрішнього права для вирішення спорів на взаємній основі, тобто шляхом укладення угоди між компетентними органами договірних держав у випадках, якщо податок стягується або може бути стягнуто не у відповідності з положеннями податкового договору, 3 метою забезпечення узгодженого застосування та тлумачення відповідного податкового договору в обох договірних державах» [8, с. 459]. 3 урахуванням викладеного навряд чи можна погодитися з підходом Е. Крістіанс, яка відносить взаємоузгоджувальну процедуру до механізмів вирішення податкових спорів, наділених дипломатичною природою: «Взаємна угода (mutual agreement) є більш ніж столітнім дипломатичним рішенням, стандартною формою неформальної дипломатичної мови щодо вирішення спорів (informal diplomatic dispute resolution language), яка закріплена у більшості податкових договорів по всьому світу» [3, с. 1433].

Існуючий підхід до тлумачення сутності взаємоузгоджувальної процедури передбачає виокремлення таких особливостей:

1) нормативною основою процедури взаємного узгодження $є$ положення договору про уникнення подвійного оподаткування, аналогічні ст. 25 Модельної 


\section{СУТНІСТЬ, ЕВОЛЮЦІЯ ТА РОЛЬ ВЗАЕМОУЗГОДЖУВАЛЬНОЇ ПРОЦЕДУРИ ЯК МЕХАНІЗМУ ВИРІШЕННЯ ПОДАТКОВИХ СПОРІВ}

податкової конвенції ОЕСР (далі - МПК ОЕСР) або ст. 25 Типової конвенції $\mathrm{OOH}$ про уникнення подвійного оподаткування у відносинах між розвиненими державами та державами, що розвиваються (далі - Типова конвенція ООН);

2) взаємоузгоджувальна процедура використовується, насамперед, для вирішення спорів, які виникають 3 приводу тлумачення та застосування положень договорів про уникнення подвійного оподаткування, а не внутрішнього законодавства: «якщо стягнення податку суперечить як податковому договору, так і внутрішньодержавному праву, то такий випадок підпадає під вимоги взаємоузгоджувальної процедури лише в тому обсязі, в якому він стосується податкового договору, за виключенням ситуацій, коли існує взаємозв'язок між положеннями податкового договору та положеннями внутрішнього права, яке неналежним чином застосовується» [5, с. 1741];

3) за результатами успішної процедури взаємного узгодження між компетентними органами договірних держав укладається угода щодо тлумачення чи застосування положень договору про уникнення подвійного оподаткування;

4) взаємоузгоджувальна процедура є останнім засобом для вирішення спору на засадах взаємності та без використання дипломатичних каналів [7, c. 687].

Найбільш поширеними підставами для ініціювання взаємоузгоджувальної процедури є [5, с. 1741]:

1) питання, пов'язані 3 віднесенням прибутків до постійного представництва відповідно до договірних норм аналогічних п. 2 ст. 7 МПК OECP;

2) оподаткування в державі джерела доходу при наявності особливих зв'язків між платником та отримувачем доходу розміру суми перевищення процентів та роялті відповідно до договірних норм, аналогічних ст. 9, п. 6 ст. 11 чи п. 4 ст. 12 МПК ОЕСР;

3) застосування внутрішнього законодавства щодо недостатньої капіталізації у випадках, коли держава резидентства боржника розглядає проценти як дивіденди, оскільки керується договірними нормами, аналогічними ст. 9 або п. 6 ст. 11 МПК ОЕСР;

4) ситуації, в яких недостатність інформації щодо дійсного стану платника податків призводить до неналежного застосування договірних норм, особливо у випадку визначення резиденства (п. 2 ст. 4 МПК ОЕСР), існування постійного представництва (ст. 5 МПК ОЕСР) чи природи послуг, наданих працедавцем (п. 2 ст. 15 МПК ОЕСР).

У значній кількості випадків до взаємоузгоджувальної процедури звертаються у випадку укладення договорів про попереднє узгодження ціноутворення дво- чи багатостороннього характеру (advance pricing 
agreements). Наприклад, Національне податкове агентство Японії за підсумками 2014 р. відзвітувало про те, що іiі співробітниками було отримано всього 187 запитів щодо процедури взаємного узгодження як від платників податків, так і компетентних органів договірних держав-партнерів. 3 них 149 запитів стосувалися можливості укладення договорів про попереднє узгодження ціноутворення [12, с. 40].

Найчастіше виокремлюють три основні види взаємоузгоджувальної процедури на підставі характерних для неї функцій (на прикладі положень ст. 25 МПК ОЕСР [10, с. 44-45; 8, с. 462]:

1) Вирішення спорів щодо застосування положень договірних норм у сфері оподаткування в конкретному випадку (положення про конкретний випадок);

2) Визначення спільного підходу до тлумачення та застосування компетентними органами договору про уникнення подвійного оподаткування (тлумачна взаємоузгоджувальна процедура). Наприклад, узгодження спільного підходу компетентних органів до тлумачення того чи іншого договірного терміну («резидент», «проценти», «роялті» та ін.);

3) Вирішення спорів щодо подвійного оподаткування у випадку, якщо таке оподаткування не охоплене дією договірних норм у сфері оподаткування (нормотворча взаємоузгоджувальна процедура). Наприклад, якщо нерезидент має постійні представництва в договірних державах, але за відсутності резидентства в них не має доступу до переваг договору про уникнення подвійного оподаткування між такими державами [1, с. 5].

Очевидно, що перший вид взаємоузгоджувальної процедури може бути ініційований виключно за наявності звернення платника податків, однак два наступні види відповідної процедури не потребують в обов'язковому порядку звернення платника податків та можуть бути розпочаті компетентними органами договірних держав за власною ініціативою.

3 ретроспективної точки зору вперше праобраз сучасного п. 1 ст. 25 МПК ОЕСР з'явився у проекті Модельної двосторонньої конвенції про уникнення подвійного оподаткування на дохід, розробленому Фіскальним комітетом Ліги Націй та запропонованому у 1942 р. (ст. XVI): «1. Якщо платник податків має докази того, що дії податкового відомства однієї 3 договірних держав мають наслідком подвійне оподаткування, то такий платник податків повинен мати право на звернення (shall be entitled to lodge a claim) до податкового відомства держави, в якій він має фіскальний доміциль чи громадянином якої він є. 2. У випадку прийняття звернення ... податкове відомство відповідної держави має безпосередньо проводити консультації 3 компетентним органом іншої держави в намаганні досягнути згоди щодо справедливого уникнення від подвійного оподаткування» [13, с. 26, 28]. 


\section{СУТНІСТЬ, ЕВОЛЮЦІЯ ТА РОЛЬ ВЗАЕМОУЗГОДЖУВАЛЬНОЇ ПРОЦЕДУРИ ЯК МЕХАНІЗМУ ВИРІШЕННЯ ПОДАТКОВИХ СПОРІВ}

У ст. XVII того ж проекту 1942 р. вперше з'явиласz згадка і про праобраз сучасного положення про нормотворчу взаємоузгоджувальну процедуру, запропоноване у другому реченні п. 3 ст. 25 МПК ОЕСР: «У випадку будь-яких спеціальних положень, які можуть бути необхідними для застосування цієї конвенції, особливо у випадках, безпосередньо не передбачених у ній, компетентні органи обох договірних держав можуть спільно радитися (confertogether) і вживати необхідних заходів відповідно до духу цієї конвенці» $[13$, c. 28$]$.

Тлумачна взаємоузгоджувальна процедура, яка наразі закріплена у першому реченні п. 3 ст. 25 МПК ОЕСР, не була включена Фіскальним комітетом Ліги Націй уМодельну двосторонню конвенцію про уникнення подвійного оподаткування на дохід, але вона була передбачена у ст. VII проекту Модельної двосторонньої конвенції Ліги Націй про надання взаємної адміністративної допомоги в оцінці та збиранні податків 3 доходу, власності, майна та спадщини, який з'явився в той же час: «Компетентні органи обох договірних держав можуть визначати положення (prescriberegulations), необхідні для тлумачення та застосування положень цієї конвенції. У випадку положень цієї конвенції щодо обміну інформацією, надання документів чи взаємної допомоги у збиранні податків такі органи можуть, за спільною згодою, визначати правила щодо процедури, форм звернення та відповідей, конвертації валюти, розпорядження зібраними податками, мінімальних сум для стягування податку та ін.» [13, с. 64]. Існування такого положення у результатах модельної нормотворчості Фіскального комітету Ліги Націй ще у 1942 р. ставить питання про обгрунтованість твердження М. Ніттеля про те, що тлумачна взаємоузгоджувальна процедура була закріплена у модельних нормах Фіскального комітету Ліги Націй лише у 1946 р. [7, с. 688-689].

Напрацювання Фіскального комітету Ліги Націй не були залишені без уваги у роботі над розробкою модельних норм у сфері оподаткування в рамках ОЕСР та ООН і втілені відповідно у проекті МПК ОЕСР у редакції 1977 р. та проекті Типової конвенції ООН у редакції 1979 р. Разом із тим, варто зазначити, що запозичення такого досвіду не мало автоматичного характеру, про свідчить, наприклад, наявність особливостей у підході ОЕСР, які відрізняли його від підходу Ліги Націй: 1) правом на звернення до взаємоузгоджувальної процедури наділено насамперед резидентів і лише у порядку виключення - громадян та юридичних осіб, зареєстрованих у конкретній договірній державі, які загалом об'єднуються категорією «nationals»; 2) можливість звернення платника податків до взаємоузгоджувальної процедури обмежено трирічним строком 3 моменту, коли йому стало відомо про оподаткування або імовірність оподаткування не у відповідності 3 вимогами договірних норм у сфері оподаткування; 3) предметна сфера взаємоузгоджувальної процедури не 


\section{СУТНІСТЬ, ЕВОЛЮЦІЯ ТА РОЛЬ ВЗАЕМОУЗГОДЖУВАЛЬНОЇ ПРОЦЕДУРИ ЯК МЕХАНІЗМУ ВИРІШЕННЯ ПОДАТКОВИХ СПОРІВ}

обмежується лише питаннями уникнення подвійного оподаткування, а визначається через концепцію оподаткування не у відповідності 3 вимогами договірних норм, окрім випадків нормотворчої взаємоузгоджувальної процедури; 4) запровадження положення про обов'язок імплементації вимог досягнутої взаємної згоди між компетентними органами незалежно від будьяких часових рамок встановлених у національних правопорядках договірних держав; 5) запроваджено положення про те, що право на звернення до потенціалу взаємоузгоджувальної процедури платник податків має не лише тоді, коли оподаткування не у відповідності з договірними нормами вже фактично відбулося, але й коли існує тільки об'єктивна загроза такого оподаткування (наприклад, прийняття нового нормативного акту, який безпосередньо передбачає відступ від договірних зобов’язань держави у сфері оподаткування); 6) у випадку доцільності пропонувалося створення комісії для заслуховування аргументів, яка має включати в себе представників компетентних органів один одного.

Істотним кроком у розвитку положень про взаємоузгоджувальну процедуру 3 моменту розробки модельних норм ОЕСР та ООН у сфері оподаткування стало прийняття норми про арбітраж у випадку неможливості досягнення згоди між сторонами 3 питань, які порушені в рамках взаємоузгоджувальної процедури. Необхідні зміни першими були внесені в МПК ОЕСР за результатами доповіді «Зміни 2008 року до Модельної податкової конвенції», затвердженої Радою ОЕСР 17.07.2008 р.

Арбітражна процедура не має розумітися як альтернатива взаємоузгоджувальній процедурі, а є продовженням останньої у тому випадку, якщо компетентним органам не вдається досягти згоди між собою. Експерти ОЕСР зазначали: «Оскільки взаємоузгоджувальна процедура у нинішньому вигляді не зобов'язує держави знайти спільне розуміння щодо договору, але лише намагатися (endeavor) досягти згоди, то результатом може стати тягар подвійного оподаткування чи «оподаткування не у відповідності з конвенцією», якщо сторони не досягають згоди. Неможливість взаємоузгоджувальної процедури в існуючому вигляді забезпечити здійснення усіх необхідних кроків для сприяння остаточному вирішенню проблем, які виникли у зв'язку 3 договором, визнається ... однією 3 найбільш суттєвих перешкод для ефективності взаємоузгоджувальної процедури. Вона зумовлює те, що платники податків зволікають 3 залученням необхідних ресурсів для використання взаємоузгоджувальної процедури та, до того ж, не стимулює компетентні органи до здійснення усіх необхідних кроків для забезпечення швидкого вирішення питань, які виникли. У такому випадку, на думку експертів ОЕСР, арбітражна процедура є незамінним інструментом, який сприяє вирішенню проблемної 


\section{СУТНІСТЬ, ЕВОЛЮЦІЯ ТА РОЛЬ ВЗАЕМОУЗГОДЖУВАЛЬНОЇ ПРОЦЕДУРИ ЯК МЕХАНІЗМУ ВИРІШЕННЯ ПОДАТКОВИХ СПОРІВ}

ситуації у остаточний, визначений (principled), справедливий та об’єктивний спосіб [4, с. 4].

Тривала практика використання потенціалу взаємоузгоджувальної процедури свідчить про іiі важливість як інструменту вирішення спорів 3 приводу тлумачення та застосування договірних норм у сфері оподаткування. Переваги взаємоузгоджувальної процедури С. Кім пропонує розмежувати в залежності від кола зацікавлених у іiі використанні осіб - переваги для податкових відомств та для платників податків [6, с. 46-58]:

1. Для податкових відомств:

- збереження контролю зі сторони компетентних органів за перебігом взаємоузгоджувальної процедури та результатом ії завершення, що дає їм змогу обмежити можливі негативні наслідки для забезпечення суверенітету у сфері оподаткування;

- природа взаємоузгоджувальної процедури як «доповнення до незавершених договірних перемовин» дозволяє забезпечити менш формалізовані та більш комфортні умови взаємодії договірних сторін;

- зменшення репутаційних ризиків для компетентних органів при проведенні взаємоузгоджувальної процедури 3 урахуванням іiі закритого характеру;

- збереження повноважень податкового відомства щодо початку чи відмови у початку взаємоузгоджувальної процедури дає змогу більш ефективно витрачати наявні обмежені ресурси (наприклад, у випадку неналежної поведінки платника податків);

- менш формалізований характер взаємоузгоджувальної процедури сприяє зменшенню часових втрат та налагодженню безпосередніх контактів представників компетентних органів, що, в свою чергу, забезпечує обмін кращим досвідом та передовими підходами;

- гнучкість взаємоузгоджувальної процедури;

- менші адміністративні витрати взаємоузгоджувальної процедури порівняно з іншими можливими інструментами вирішення міжнародних спорів, такими як міжнародні трибунали чи міжнародні судові інстанції;

- закритий характер взаємоузгоджувальної процедури дозволяє обмежити зовнішній вплив на фахове рішення представників компетентних органів.

2. Для платників податків:

- фахове вирішення спору представниками компетентних органів за низьких витрат (у тому випадку, якщо доступ до взаємоузгоджувальної процедури не передбачає попереднього забезпечення спірного податкового зобов’ язання); 
- можливість запобігання майбутнім негативним сценаріям 3 точки зору оподаткування у випадку нових підходів або податкових стратегій через підтримку фахового діалогу в рамках взаємоузгоджувальної процедури;

- підвищений рівень конфіденційності за рахунок закритості та непрозорості взаємоузгоджувальної процедури, що зменшує можливість стороннього впливу та репутаційних втрат;

- результати взаємоузгоджувальної процедури не є зобов'язуючими платника податків автоматично, а потребують свого визнання таким платником податків;

- неформальність та гнучкість взаємоузгоджувальної процедури у поєднанні з їі неконтроверсійною природою зменшує ризик того, що податкові відомства розглядатимуть процес вирішення конкретної ситуації саме як спір та застосовуватимуть «неформальні штрафні санкції», такі як більш прискіпливий аудит (разом $з$ тим така перевага може існувати лише у тому випадку, якщо урядові цілі та цілі платника податків у конкретному випадку не суперечать одне одному).

Наявність позитивних характеристик у використанні взаємоузгоджувальної процедури не виключає можливості існування недоліків чи проблемних аспектів, які ускладнюють повноцінну реалізацію потенціалу відповідного механізму вирішення спорів. Так, П. Браун до числа останніх відносить [2, с. 5]; 1) взаємоузгоджувальна процедура найчастіше передбачає обов'язок не досягнення конкретної угоди, а лише прагнути укладення такої угоди; 2) більшість договорів про уникнення подвійного оподаткування не передбачає часових рамок для тривалості розгляду компетентними органами конкретного звернення в рамках взаємоузгоджувальної процедури; 3) ризики ефекту «чорної скриньки» 3 урахуванням міжвідомчого характеру взаємоузгоджувальної процедури та обмеженої форми участі платників податків.

Висновки. Взаємоузгоджувальна процедура $\epsilon$ важливим договірним механізмом вирішення спорів щодо тлумачення та застосування норм договорів про уникнення подвійного оподаткування. Тривала практика використання такого механізму підтверджує виправданість його існування у сучасному світі 3 точки зору наявних переваг не лише для компетентних органів, але i для платників податків. Разом 3 тим, обмежена практика його використання у поєднанні з наявністю проблемних аспектів у контексті забезпечення балансу публічного та приватного інтересу у сфері оподаткування переконує у тому, що потенціал взаємоузгоджувальної процедури використовується ще далеко не в повній мірі. Очевидно, що в умовах високого рівня недовіри до дій судової та виконавчої гілок в Україні та необхідності забезпечення інвестиційної привабливості взаємоузгоджувальна процедура $є$ потенційно перспективним 
інструментом 3 точки зору забезпечення балансу приватного та публічного інтересу.

\section{Список використаних джерел:}

1. Ault, H. Dispute Resolution: the Mutual Agreement Procedure [Electronic resource] : Paper № 8-A, 2013. - May. - 29 p. - Mode of access: URL: http://www.un.org/esa/ffd/tax/2013TMTTAN/Paper8A_Ault.pdf. - Last access 17.01.2018. - Title from the screen.

2. Brown P. Enhancing the mutualagree mentpro cedureby adoptingap propriate arbitration provisions [Electronic resource] / P. Brown // Vienna University of Economics and Business. - Vienna, $16 \mathrm{p}$. - Mode of access: URL: https://www.wu.ac.at/fileadmin/wu/d/i/taxlaw/institute/ WU_Global_Tax_Policy_Center/Arbitration/patricia_brown on_current_trends_in_ map.docx. - Last access 17.01.2018. - Title from the screen.

3. Christians A. How Nations Share / A. Christians // Indiana Law Journal. 2012. - Vol. 87. - pp. 1407-1453.

4. Improving the Resolution of Tax Treaty Disputes [Electronic resource] // Centre for Tax Policy and Administration, 2007. - February. - 52 p. - Mode of access: URl: https://www.oecd.org/ctp/dispute/38055311.pdf. - Last access 19.01.2018. - Title from the screen.

5. Ismer R. Mutual Agreement Procedure. Klaus Vogelon Double Taxation Convention / R. Ismer ; ed. by E. Reimer, A. Rust. - 4th ed. - Wolters Kluwer, 2015. - Vol. 2.Alphenaanden Rijn. - Article 25. - pp. 1735-1826.

6. Kim S. Study on Arbitrationas Institution of International Tax Dispute Resolution: Within the Ambit of MAP as Suggestedbythe OECD [Electronic resource] / S. Kim // Seoul National University School of Law, 2014. - February. - 383 p. Mode of access: URL: http://sspace.snu.ac.kr/bitstream/10371/120836/1/000000017842.pdf. - Last access 20.01.2018. - Title from the screen.

7. Knittel M. Administrative Cooperation. History of Tax Treaties. The Relevance of the OECD Documents for the Interpretation of Tax Treaties / M. Knitte ; ed. by T. Eckerand, G. Ressler. - Wien : Linde, 2011. - Articles 25, 26 and 27. pp. 685-713.

8. Lombardo M. The Mutual Agreement Procedure (Art. 25 OECD MC) - A Toolto Over come Interpretation problems? / M. Lombardo // Fundamental Issues and Practical Problem sin Tax Treaty Interpretation ; Ed. by M. Schilcherand, P. Weninger. - Wien : LINDE, 2008. - pp. 457-480.

9. Manual of Effective Mutual Agreement Procedures [Electronic resource] / MEMAP ; Centre for Tax Policy and Administration. - 2007. - February. - 55 p. - 
Mode of access: URL: https://www.oecd.org/ctp/38061910.pdf. - Last access 21.01.2018. - Title from the screen.

10. Model Tax Conventionon Incomeandon Capital. Condensed Version (as it read on 21 November 2017). - Paris : OECD Publishing, 2017. - 654 p.

11. Mutual Agreement Procedure Statistics 2006-2015 [Electronic resource] / OECD. - Mode of access: URL: http://www.oecd.org/tax/dispute/map-statistics-20062015.htm. - Last access 23.01.2018. - Title from the screen.

12. National Tax Agency [Electronic resource] : Report 2016 / National Tax Agency of Japan. - $66 \mathrm{p}$. - Mode of access: URL: https://www.nta.go.jp/foreign_language/Report_pdf/2016e.pdf. - Last access 25.01.2018. - Title from the screen.

13. Reporton the Workof the Tenth Sessionof the Fiscal Committee [Electronic resource] Geneva : League of Nations, 1946. - 79 p. - Mode of access: URL: $\quad$ http://biblio-archive.unog.ch/Dateien/CouncilMSD/C-37-M-37-1946-IIA_EN.pdf. - Last access 25.01.2018. - Title from the screen.

\section{References:}

1. Ault, H. (2013). Dispute Resolution: theMutual Agreement Procedure, Paper № 8-A. [online] Available at : URL: http://www.un.org/esa/ffd/tax/2013TMTTAN/Paper8A_Ault.pdf. [Accessed 17 January 2018]. Title from the screen.

2. Brown, P. Enhancing the mutualagree mentpro cedureby adoptingap propriate arbitration provisions. Vienna, Vienna University of Economics and Business. [online] Available at : URL: https://www.wu.ac.at/fileadmin/wu/d/i/taxlaw/institute/ WU_Global_Tax_Policy_Center/Arbitration/patricia_brown__on_current_trends_in_ map.docx. [Accessed 17 January 2018]. Title from the screen.

3. Christians, A. (2012). How Nations Share. Indiana Law Journal, Vol. 87, pp. 1407-1453.

4. Centre for Tax Policy and Administration. (2007). Improving the Resolution of Tax Treaty Disputes. [online] Available at : URl: https://www.oecd.org/ctp/dispute/38055311.pdf (Last assessed: 05.02.2018). [Accessed 19 January 2018]. Title from the screen.

5. Ismer, R. (2015). Mutual Agreement Procedure. Klaus Vogelon Double Taxation Convention. 4th ed. Wolters Kluwer, Vol. 2, Article 25, pp. 1735-1826.

6. Kim, S. (2014). Study on Arbitrationas Institution of International Tax Dispute Resolution: Within the Ambit of MAP as Suggestedbythe OECD. Seoul National University School of Law. [online] Available at : URL: http://sspace.snu.ac.kr/bitstream/10371/120836/1/000000017842.pdf. [Accessed 20 January 2018]. Title from the screen. 
7. Knittel, M. (2011). Administrative Cooperation. History of Tax Treaties. The Relevance of the OECD Documents for the Interpretation of Tax Treaties. Articles 25, 26 and 27. Wien : Linde.

8. Lombardo, M. (2008). The Mutual Agreement Procedure (Art. 25 OECD MC) - A Toolto Over come Interpretation problems? V: Fundamental Issues and Practical Problem sin Tax Treaty Interpretation. Wien : LINDE.

9. Centre for Tax Policy and Administration. (2007). Manual of Effective Mutual Agreement Procedures. [online] Available at : URL: https://www.oecd.org/ctp/38061910.pdf. [Accessed 21 January 2018]. Title from the screen.

10. OECD. (2017). Model Tax Conventionon Incomeandon Capital. Condensed Version (November 21, 2017). Paris : OECD Publishing.

11. OECD. (2015). Mutual Agreement Procedure Statistics 2006-2015. [online] Available at : URL: http://www.oecd.org/tax/dispute/map-statistics-20062015.htm. [Accessed 23 January 2018]. Title from the screen.

12. National Tax Agency of Japan. (2016). Report 2016. V: National Tax Agency. [online] Available at: URL: https://www.nta.go.jp/foreign_language/Report_pdf/2016e.pdf. [Accessed 25 January 2018]. Title from the screen.

13. League of Nations. (1946). Reporton the Workof the Tenth Sessionof the Fiscal Committee. [online] Available at : URL: http://biblioarchive.unog.ch/Dateien/CouncilMSD/C-37-M-37-1946-II-A_EN.pdf. [Accessed 25 January 2019]. Title from the screen.

(С Селезень П.О., 2018 